\title{
Miocene Slănic Tuff, Eastern Carpathians, Romania, in the Context of Badenian Salinity Crisis
}

\author{
Ana-Voica Bojar ${ }^{1,2, *} \mathbb{1}$, Victor Barbu $^{3} \mathbb{E}^{\mathbb{D}}$, Artur Wojtowicz ${ }^{4}$, Hans-Peter Bojar ${ }^{2}$, \\ Stanisław Hałas ${ }^{4}$ and Octavian G. Duliu 5 (i) \\ 1 Geographie und Geologie, Salzburg University, Hellbrunnerstraße 34, 5020 Salzburg, Austria \\ 2 Studienzentrum Naturkunde Mineralogie, Universalmuseum Joanneum, Weinzöttlstraße 16, \\ 8045 Graz, Austria; hans-peter.bojar@museum-joanneum.at \\ 3 OMV Petrom, 22 Coralilor, 013329 Bucharest, Romania; barbu.victor@gmail.com \\ 4 Mass Spectrometry Laboratory, Institute of Physics, Maria Curie-Sklodowska University, \\ Plac MariiSkłodowskiej-Curie 5, 20-400 Lublin, Poland; wujek@outlook.com (A.W.); \\ stanislaw.halas@poczta.umcs.lublin.pl (S.H.) \\ 5 Department of Structure of Matter, Earth and Atmospheric Physics and Astrophysics, Faculty of Physics, \\ University of Bucharest, Bulevardul Regina Elisabeta 4-12, 030018 București, Romania; \\ o.duliu@fizica.unibuc.ro \\ * Correspondence: ana-voica.bojar@sbg.ac.at
}

Received: 20 December 2017; Accepted: 13 February 2018; Published: 18 February 2018

\begin{abstract}
New geochronological investigations for the Slănic Formation, correlated with previous bioand lithostratigaphical information, allow for a better succession of events for the Middle Miocene, including the absolute age of the Badenian salinity crisis in the bend sector of the Eastern Carpathians. Within the green Slănic Tuff, white tuff layers were in evidence. The main element distribution of the white and green tuffs indicates a dacitic composition, with higher $\mathrm{SiO}_{2}$ content for the white tuff. The white tuff has a distinct mineralogical composition with quartz, plagioclase, biotite and clinoptilolite. From such a tuff layer a biotite concentrate gives a ${ }^{40} \mathrm{Ar} /{ }^{39} \mathrm{Ar}$ age of $13.7 \pm 0.2 \mathrm{Ma}$. As above these tuff layers discrete levels of gypsum occur, the age documents the beginning of the restrictive circulation and formation of evaporites in this sector of Carpathians during Badenian times.
\end{abstract}

Keywords: Slănic tuff; geochemistry; mineralogy; absolute age; Neogene climates; salinity crisis; Eastern Carpathians

\section{Introduction}

Miocene tuffs of calc-alkaline composition are widespread in the Carpathians, Pannonian and Eastern Alpine realm. Their occurrences are described in outcrops as well as in the subsurface. The presence of tuffs may offer important criteria for stratigraphic correlations allowing the determination of the absolute age of deposits and associated climatic and environmental changes. For example, Miocene tuffs have been described for the Transylvania Basin [1-3], the Getic basin [4], the Maramureş Basin [5,6], the Gutâi Mts. [7], the Apuseni Mts. [8], the Abrămuț Basin (part of the eastern Pannonian basin) [9], the Beregovo and northern Trans-Tisza regions [10] and the Styrian Basin [11,12].

In contrast, in the outer Carpathian arc, the occurrences of Badenian tuffs are scarce in comparison with the inner Carpathian areas. For example, investigations have been done for the Slănic Formation in the foreland of the Eastern Carpathians [13,14].

In this study, we integrated previous bio- and lithostratigraphical information with new mineralogical, geochemical and geochronological data for the Slănic Formation, which is situated in the foreland of the Eastern Carpathians. The aim is to correlate the position of this tuff with other Miocene occurrences situated in the Carpathian area in order to get a better regional geochronological image 
regarding the position of tuffs with respect to the Badenian salinity event. Finally, the Carpathian events are correlated with some of the worldwide-established biostratigraphical events.

\section{Geological Setting}

The Slănic tuff deposits are part of Mid Miocene (Badenian-mid Sarmatian) post-tectonic succession (mollase deposits) of the Tarcău Nappe belonging to the Outer Flysch Zone of the Eastern Carpathians known as the Moldavides [15] (Figure 1A). The Badenian succession overlies the Burdigalian Doftana Formation [16] and is represented by marls, green tuffs, evaporites and shales [17-19] (Figure 2).

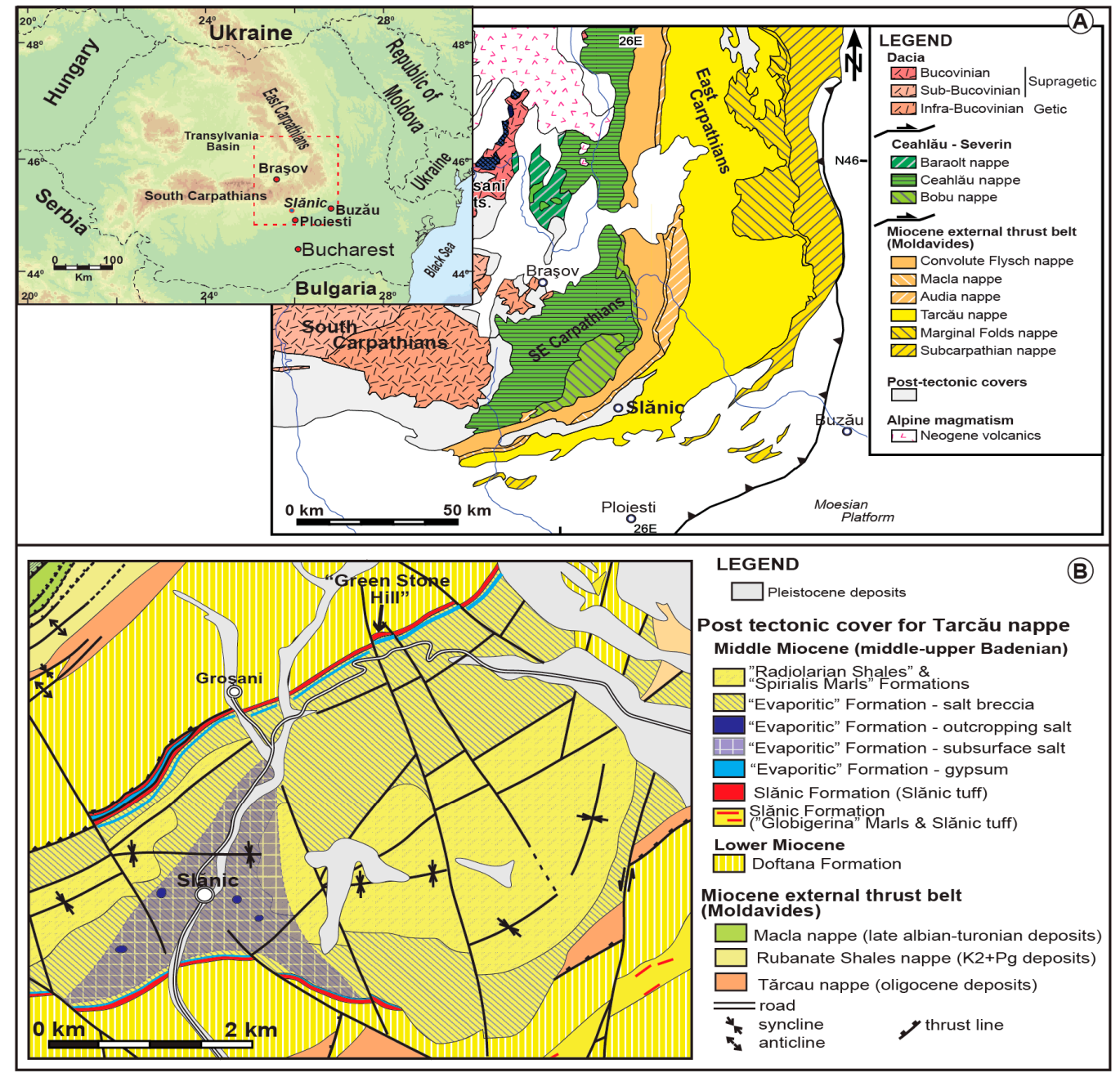

Figure 1. (A) Romania map with Slănic Prahova location and simplified map of the SE Carpathians with location of the investigated area (after Săndulescu, 1984 [15]; Visarion et al., 1988 [20]; Maţenco et al., 2003 [21] with modification); (B) Detailed geological map with the position of the investigated outcrop—Green Stone Hill (after Ştefănescu et al., 1978 [22] with modification).

The tuff deposits are exposed at the Green Stone Hill (Muntele Piatra Verde) situated in the northern flank of Slănic syncline (Figure 1B), which is well known for the diapiric salt located in the central part. There, the salt is around $500 \mathrm{~m}$ in thickness and is actively mined just below the Slănic locality. The Green Stone Hill outcrop section has been earlier described by [23-25]. The outcrop consists of (a) Slănic Formation with Globigerina Marls followed by the Slănic green tuff. Within the Slănic tuff discrete layers of gypsum and white tuffs rich in biotite occur (Figure 2). The tuffs are covered by the (b) Evaporitic Formation comprising salt breccia, massive halite and gypsum as continuous layers or lenses. The evaporites 
are covered by the Radiolarian Shales Formation, which contains rich radiolarian assemblages with Coenosphaera, Dictyocoryne, Halicapsa, Rhopalodictyum, Sethocapsa and Spongodiscus [26]. The succession ends with the Spirialis Marl Formation. The stratigraphic age of this is indicated by the Globorotalia bykovae and Orbulina suturalis (Mid Badenian) and Globoturborotalia druryi and Globorotalia transsylvanica and Velapetina (Late Badenian) Foraminera Zones [27,28].

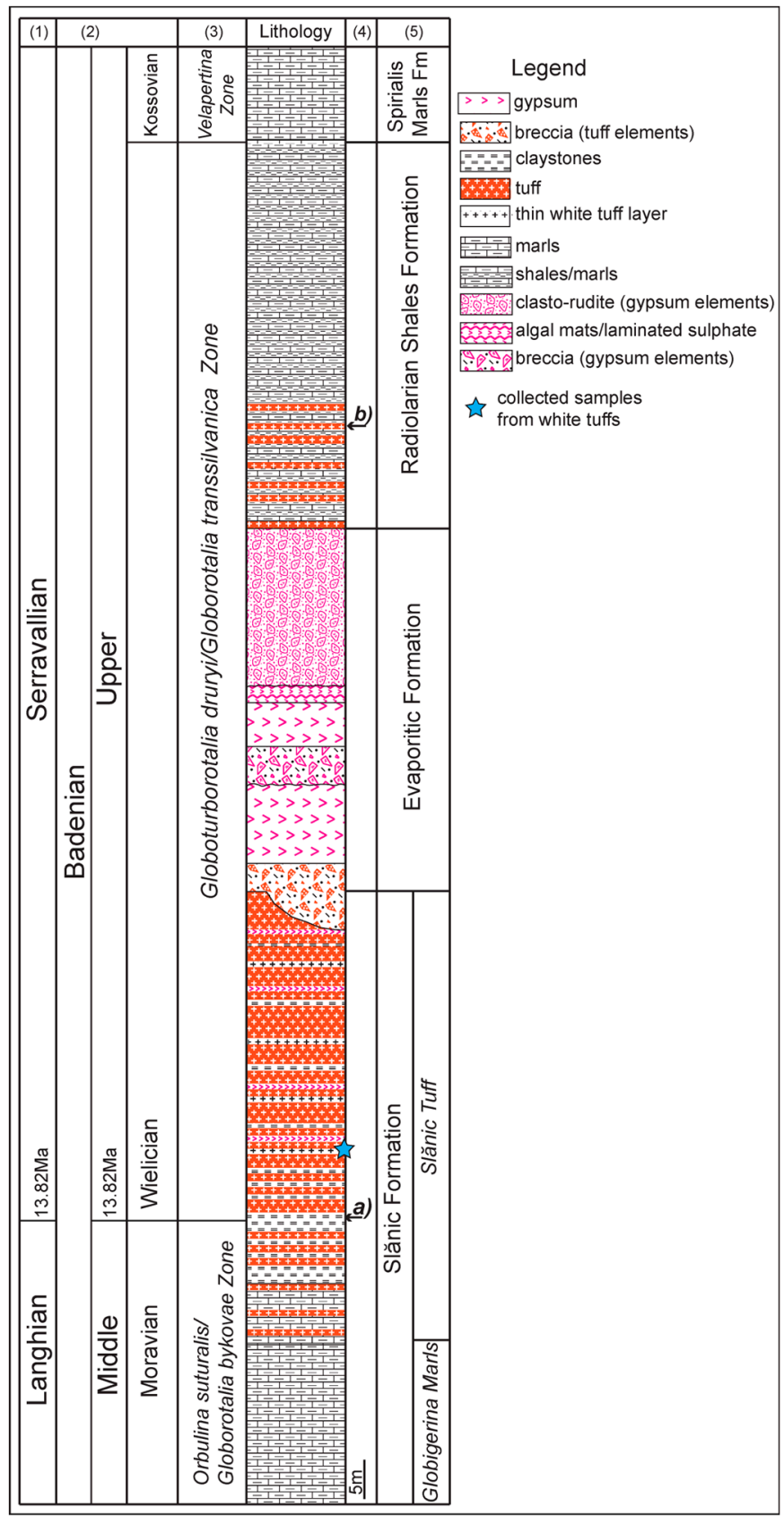

Figure 2. Lithostratigraphy at the Green Stone Hill (Muntele Piatra Verde) after [25,29] and own mapping. Position of the white tuff layer with biotite is shown. (1) Mediterranean regional stages [30]; (2) Central Paratethys regional stages [31]; (3) Forams biozonation after [17,27,28,32]; (4) Events: (a) FO Globoturborotalia druryi and FO Goborotalia transsylvanica $[17,27,28,32]$; (b) absolute age of a tuff layer (13.45 $\pm 0.06 \mathrm{Ma}$ ) after [33]; (5) Formation names for the post-tectonic cover deposits of the Tarcău nappe. 
The Globigerina Marls are characterized by an association of warm water planktonic foraminifera (Praeorbulina glomerosa, P. circularis, Orbulina suturalis, Globigerinoides triloba, G. sacculifer, Paragloborotalia mayeri, Globorotalia bykovae etc.). This forams association indicates the presences of the Globorotalia bykovae and Orbulina suturalis Planktonic Foraminifera Zone (PFZ) [27,28,32].

Just below where the tuff deposits started, within a reddish marls intercalation, the first appearance of the tropical warm species Globoturborotalia druryi was recorded, together with the first occurrence of the endemic species Globorotalia transsylvanica $[27,28]$. The first appearance of G. druryi in Paratethys marks the base of the Wielician substage $[17,27,28,32]$. G. transsylvanica is an endemic species in the Paratethys and a common Wielician species. Moreover, these two forams are used to define Globoturborotalia druryi and Globorotalia transsylvanica PFZ [27,28]. The nanofloral assemblages observed in the lower part of the Slănic Formation have been assigned to the NN5 Calcareous Nanoplankton Zone (CNZ) of [34], based on the co-occurrence of Sphenolithus heteromorphus, Helicosphaera walbersdorfensis, $H$. waltrans and H. wallichii. Based on the calcareous nanofossil association, the upper part of Slănic Formation, where the dominant lithology is represented by tuffs and was assigned by [25] to the NN6. Up to now, for this outcrop, the LO of Sphenolithus heteromorphus is not precisely determined [25] in respect to the foraminifer zonation, which was determined by $[17,27,28,32]$. Considering also the diachronous occurrence of Sphenolithus heteromorphus in the Atlantic and Mediterranean realms, the dated sample is positioned in Figure 2 to the foraminifer zonation of [32]. The uppermost part of the Slănic Formation is rich in foraminifera, the warm water planktonic foraminifera being replaced with a colder water assemblage (Globigerina bulloides, G. concinna, Globigerinita uvula etc.). Unlike the lower part of the Slănic Formation almost devoid of benthonic forminifera, from this interval a rich typical Wielician type association with Pseudotriplasia minuta, Uvigerina orbignyana and other rather deep water species (Glandulina laevigata, Sphaeroidina bulloides, Melonis pompilioides etc.) was recorded [27]. For the Evaporite Formation was not described any foraminifera or calcareous nanoplankton associations.

Based on the planktonic foraminifera association, the Radiolarian Shales Formation (containing G. transsylvanica, G. druryi, G. bykovae, P. mayeri, G. triloba, G. bulloides, P. glomerosa, P. sicana, O. suturalis, Globoturborotalita woodi, Globigerina cf. tarchanensi) is assigned to Globoturborotalia druryi \& Globorotalia transsylvanica PFZ. The calcareous nanofossil association indicated the presence of NN6 [25] fact also supported by the absolute age of a tuff intercalation dated by [33] at 13.45 \pm 0.06 Ma (Figure 2).

The last formation outcropping in Green Stone Hill is the Spirialis Formation. The foraminifera association was described contain different species of Velapertina genus (e.g., V. indigena, V. luczkowskae) and indicated by the presence of Kossovian substage (upper part of Late Badenian, Velapertina Foraminifera Range Zone after $[27,28]$ ) (Figure 2). The calcareous nanoplankton associations indicate for this interval the NN6 [13].

\section{Material and Methods}

\subsection{XRD Investigations}

Qualitative and quantitative mineralogical analysis was performed on two samples collected from the Green Stone Hill outcrop. X-ray diffraction patterns were measured on a Bruker AXS D8 diffractometer equipped with a one-dimensional strip-detector (lynx-eye) using a Cu-k $\alpha(40 \mathrm{kV}$, $40 \mathrm{~mA}$, sample rotation). The measuring conditions were: step-size $0.02^{\circ}, 2 \mathrm{sec} / \mathrm{step}$ (equivalent to $304 \mathrm{sec} /$ steps with a conventional point-detector). Mineralogical compositions are given in Figure 3. 

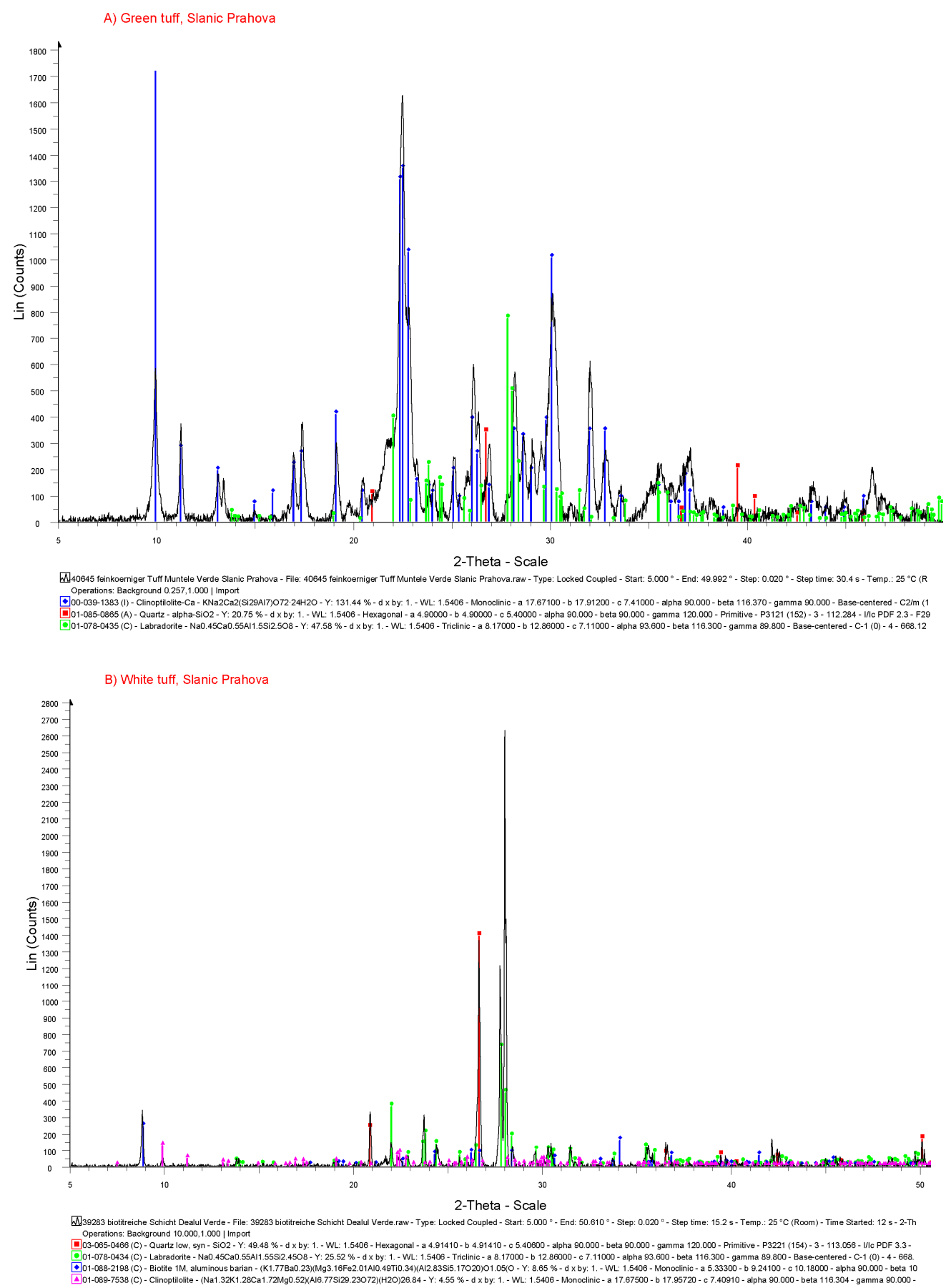

Figure 3. XRD spectra of the mineral components from: (A) green tuff and (B) white tuff, Green Stone Hill (Muntele Piatra Verde).

\subsection{Major Elements}

Two rock samples, one from the green and the other from the white tuff layers, were crushed and afterwards milled in a McCrone micronizing mill. Adsorbed water was removed at $110{ }^{\circ} \mathrm{C}$ and the loss of ignition was determined in platinum crucible at $950^{\circ} \mathrm{C}$. Half gram of the sample was mixed with $2.5 \mathrm{~g}$ lithium tetraborate and $1 \mathrm{~g}$ ammonium nitrate as oxidizer. This mixture was thoroughly homogenized in an agate mortar and molten at $1100{ }^{\circ} \mathrm{C}$. The resulting melt was cast in a moult with a flat bottom and solidified under a cold air stream. A fragment of this glass disc was embedded in epoxy resin and the surface was polished afterwards with diamond abrasives down to 1 micron. 
Quantitative analytics were performed on a Jeol $6610 \mathrm{LV}$ scanning electron microscope. $\mathrm{Mg}, \mathrm{Al}, \mathrm{Si}$, $\mathrm{K}, \mathrm{Ca}$, Ti and Fe were measured with an Oxford $50 \mathrm{~mm}^{2}$ energy dispersive detector (carbon coating, $20 \mathrm{kV}, 20 \mathrm{nA}$ ). In order to minimize beam damage, as well as to increase the measurements accuracy, the beam was set on a rectangle of $90 \times 120 \mu \mathrm{m}$. Mineral standards were used for internal calibration. Data reduction was performed with the PAP routine [35] implemented in the INCA software of Oxford Instruments. Sodium was separately determined with an Oxford wavelength dispersive system. The main element distribution is given in Table 1.

Table 1. Major element distribution for the investigated tuff samples.

\begin{tabular}{|c|c|c|c|c|c|c|c|c|c|c|}
\hline & $\mathrm{SiO}_{2}$ & $\mathrm{TiO}_{2}$ & $\mathrm{Al}_{2} \mathrm{O}_{3}$ & $\mathrm{FeO}$ & $\mathrm{CaO}$ & $\mathrm{MgO}$ & $\mathrm{Na}_{2} \mathrm{O}$ & $\mathrm{K}_{2} \mathrm{O}$ & Loss of Ignition & Total \\
\hline \multicolumn{11}{|l|}{ Green tuff } \\
\hline 1 & 76.25 & 0.6 & 12.68 & 1.41 & 4.43 & 0.2 & 1.96 & 0.86 & 5.4 & 103.79 \\
\hline 2 & 75.7 & 0.45 & 12.68 & 1.31 & 4.43 & 0.15 & 1.86 & 0.91 & 5.4 & 102.89 \\
\hline 3 & 74.59 & 0.55 & 12.42 & 1.41 & 4.58 & 0.15 & 2.52 & 0.86 & 5.4 & 102.48 \\
\hline 4 & 72.48 & 0.5 & 12.22 & 1.51 & 4.68 & 0.2 & 2.72 & 0.86 & 5.4 & 100.57 \\
\hline 5 & 70.07 & 0.4 & 11.87 & 1.41 & 4.58 & 0.2 & 3.27 & 0.91 & 5.4 & 98.11 \\
\hline 6 & 71.12 & 0.4 & 11.77 & 1.26 & 4.48 & 0.2 & 2.77 & 0.86 & 5.4 & 98.26 \\
\hline 7 & 70.37 & 0.45 & 11.82 & 1.41 & 4.58 & 0.15 & 2.26 & 0.91 & 5.4 & 97.35 \\
\hline 8 & 70.17 & 0.5 & 11.82 & 1.36 & 4.33 & 0.05 & 2.16 & 0.86 & 5.4 & 96.65 \\
\hline Average & 72.59 & 0.48 & 12.16 & 1.39 & 4.51 & 0.16 & 2.44 & 0.88 & 5.4 & 100.01 \\
\hline St. Dev. & 2.57 & 0.07 & 0.39 & 0.08 & 0.11 & 0.05 & 0.47 & 0.03 & 0.00 & 2.78 \\
\hline \multicolumn{11}{|l|}{ White tuff } \\
\hline 1 & 76.27 & 0.13 & 10.84 & 0.94 & 4.21 & 0.67 & 0.87 & 2.21 & 11.47 & 107.61 \\
\hline 2 & 68.04 & 0.13 & 9.7 & 0.87 & 4.01 & 0.6 & 0.87 & 2.14 & 11.47 & 97.83 \\
\hline 3 & 69.64 & 0.2 & 10.3 & 1.07 & 4.82 & 0.8 & 0.67 & 2.21 & 11.47 & 101.18 \\
\hline 4 & 68.91 & 0.27 & 9.83 & 0.8 & 4.01 & 0.6 & 0.87 & 2.01 & 11.47 & 98.77 \\
\hline Average & 70.72 & 0.18 & 10.17 & 0.92 & 4.26 & 0.67 & 0.82 & 2.14 & 11.47 & 101.35 \\
\hline St. Dev. & 3.76 & 0.07 & 0.52 & 0.12 & 0.38 & 0.09 & 0.10 & 0.09 & 0.00 & 4.41 \\
\hline
\end{tabular}

\section{3. ${ }^{40} \mathrm{Ar} /{ }^{\beta 9} \mathrm{Ar}$ Dating}

Biotite was concentrated from a white tuff layer. The tuff was sieved, washed and the biotites were picked up manually in the Mineralogy Department, Universalmuseum Joanneum. Biotite crystals are all of same size, with perfect crystallographic shapes and show no sign of alteration. Dating of the biotite concentrate was than performed at Mass Spectrometry Laboratory, UMCS, Lublin, Poland. For this purpose, the fraction size of $0.2-0.5 \mathrm{~mm}$ was selected. An aliquot of about $50 \mathrm{mg}$ was wrapped in an Al-foil package and marked. On both ends of package with a total length of about $30 \mathrm{~mm}$ aliquots of standard MMhb-1 were placed. This procedure allows obtaining information about the value of flux coefficient of irradiation and about the homogeneity of neutron beam during irradiation. The package was placed in a quartz ampoule evacuated and then sealed. The package was irradiated in the Ewa nuclear reactor at the National Nuclear Center in Świerk, Poland. The sample package was inserted into one of the channels in the reactor and irradiated for $100 \mathrm{~h}$ with a homogenous beam of fast neutrons. The selected channel was covered with cobalt in order to reduce the intensity of undesired thermal neutrons.

After removing the ampoule from the reactor channel, several weeks have elapsed to reduce the harmful radiation emitted by short-living radioactive isotopes generated during irradiation. Then sample and standards were taken out from the ampoule and placed in a high vacuum extraction and purification line. The gases from the sample and standards were released using step-wise technique. The expected ages of samples were relatively low and thus concentration of radiogenic ${ }^{40} \mathrm{Ar}$ isotope was also low, therefore it was decided to extract gases in two heating steps. The time of the gases extraction in each step was about $20 \mathrm{~min}$. Extracted gases were purified from non-noble gases using a getter pump. Then isotopes of argon were analyzed on a modified (with new electronics) MS-10 mass spectrometer.

Four isotopes of argon were measured: ${ }^{40} \mathrm{Ar}$ of both radiogenic and atmosphere origin, ${ }^{36} \mathrm{Ar}$ used to calculate the percent of radiogenic ${ }^{40} \mathrm{Ar}$ in total ${ }^{40} \mathrm{Ar},{ }^{39} \mathrm{Ar}$ generated in nuclear reactor from ${ }^{39} \mathrm{~K}$ 
and ${ }^{37} \mathrm{Ar}$ which was used for ${ }^{39} \mathrm{Ar}$ correction. This correction is necessary because part of ${ }^{39} \mathrm{Ar}$ is the product of neutron irradiation of ${ }^{39} \mathrm{Ca}$ isotope (Table 2).

Table 2. Results of radiometric ${ }^{40} \mathrm{Ar} /{ }^{39} \mathrm{Ar}$ dating on biotite crystals from the Slănic tuff.

\begin{tabular}{|c|c|c|c|c|c|c|c|c|}
\hline Temp. $\left[{ }^{\circ} \mathrm{C}\right]$ & ${ }^{40} \mathrm{Ar} /{ }^{39} \mathrm{Ar}$ & ${ }^{37} \mathrm{Ar} /{ }^{39} \mathrm{Ar}$ & ${ }^{36} \mathrm{Ar} /{ }^{39} \mathrm{Ar}$ & $\begin{array}{c}\text { Time after Irradiation } \\
\text { [day] }\end{array}$ & $\%$ of Total ${ }^{39} \mathrm{Ar}$ & $\%$ of ${ }^{40} \mathrm{Ar} *$ & Age [Ma] & Av. Age [Ma] \\
\hline 1050 & 3.411 & 0.001 & 0.00195 & 166.7 & 35.1 & 83.1 & $13.9 \pm 0.3$ & \multirow{2}{*}{$13.7 \pm 0.2$} \\
\hline 1200 & 3.353 & 0.001 & 0.00196 & 167.5 & 41.4 & 82.8 & $13.6 \pm 0.2$ & \\
\hline
\end{tabular}

The age in each step was calculated based on the formula: $t=(1 / \lambda) \ln (J R+1)$, where $\lambda$ is a decay constant of ${ }^{40} \mathrm{~K}, \mathrm{~J}$ is the flux coefficient, which is a parameter associated with the irradiation process, determined from measurements of argon isotopes concentration in MMhb-1 standard [36] irradiated together with the samples and $\mathrm{R}$ is the ${ }^{40} \mathrm{Ar} /{ }^{39} \mathrm{Ar}$ ratio.

\section{Discussions and Conclusions}

\subsection{Mineralogical Composition}

XRD investigation of the green Slănic tuff indicates that the main mineralogical component is clinoptilolite (zeolite) followed by quartz and plagioclase (Figure 3A). For this type of tuff there is no crystalline phase, which may be used for radiometric dating. Within the green tuff interval, we found discrete layers of a much coarser, white tuff, with mineralogy consisting of quartz, plagioclase, biotite and clinoptilolite-heulandite (Figure 3B). From a white tuff layer (Figure 2) a biotite concentrate was prepared and dated using the ${ }^{40} \mathrm{Ar} /{ }^{39} \mathrm{Ar}$ technique. The determined mineralogical composition of the green tuff is consistent with the data of [14] and [4]. According to [14] the Si:Al ratio of the clinoptilolite-heulandite framework typology zeolite from Slanic Prahova is $>4$ and therefore clinoptilolite [37]. The occurrence of clinoptilolite indicates similarities with the tuffs from the Getic basin [4], Transylvania basin [2] or Coştui-Maramureş basin [6]. For the Abrămuț basin, that is located in eastern part of Pannonian basin, the main zeolite determined in Badenian tuff layers was analcime, indicating that the tuffs were heated during burial process at the temperature over $60^{\circ} \mathrm{C}$ to $80^{\circ} \mathrm{C}$, but less than the temperature requested in order to cross the analcime-albite boundary [9]. For this study, the absence of albite in XRD spectra analysis confirmed that the tuff samples are in the analcime zone. According to [38], the analcime to albite transition take place at $123^{\circ} \mathrm{C}$. In contrast to the Abrămut basin, in the Transylvanian basin, the burial temperature for tuffs was estimated at $80^{\circ} \pm 10^{\circ} \mathrm{C}[2,39]$ that is in the estimated range for clinoptilolite formation and stability $[38,40]$. For the present investigated case, the presence of clinoptilolite in Slănic tuff indicates that during the burial process the temperature was not crossing the analcime zone.

\subsection{Major Element Composition}

Previous major element compositions of tuffs are given in Figure 4. The present investigated samples indicate similar alkali contents (Table 1), the white tuff showing a higher $\mathrm{SiO}_{2}$ content in comparison to the green tuff (Figure 4). The white tuff is at the limit between the dacitic and the rhyolitic fields, representing the most $\mathrm{SiO}_{2}$ enriched tuff, which has been put in evidence for the external Carpathians area. 


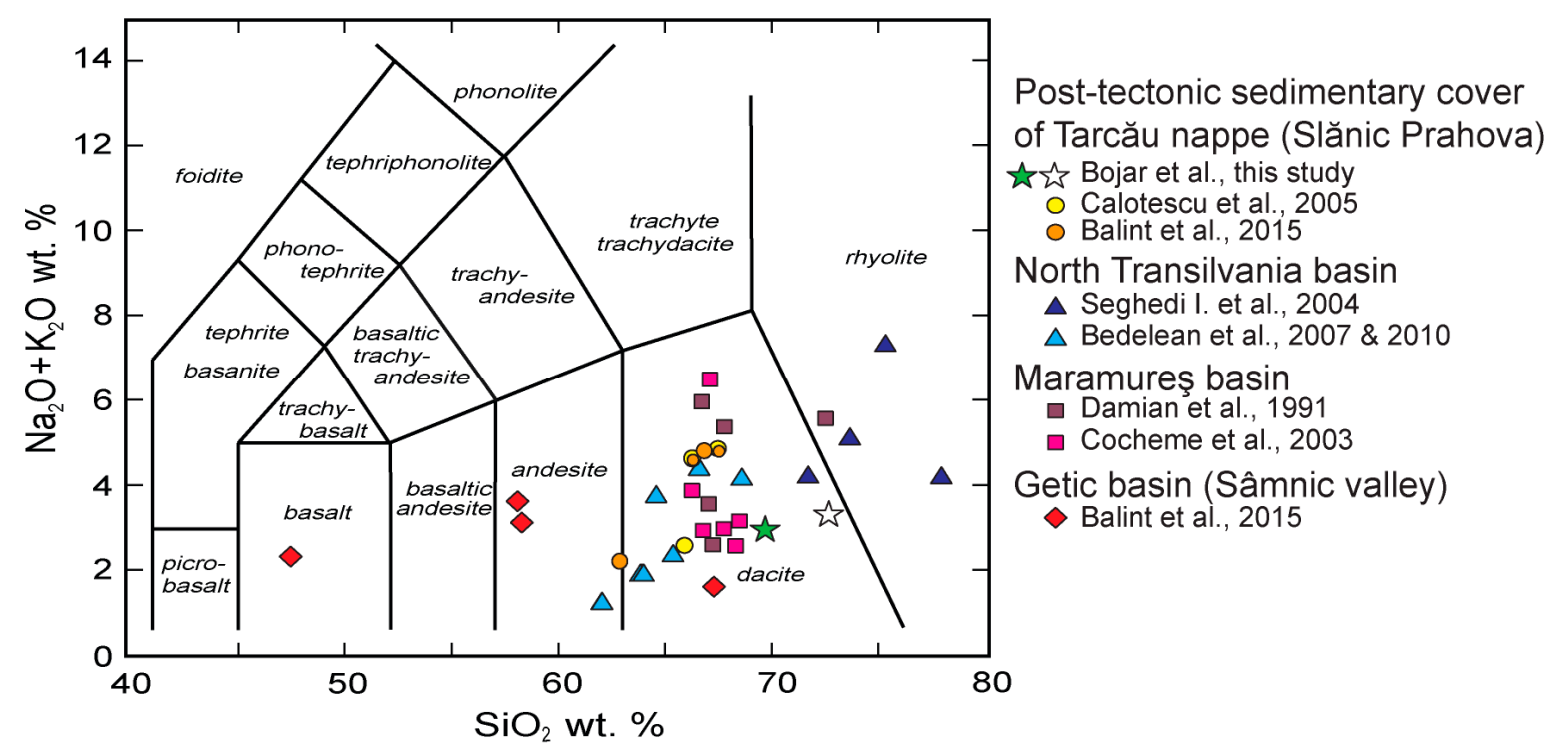

Figure 4. Position in a $\mathrm{SiO}_{2}$ vs. $\left(\mathrm{Na}_{2} \mathrm{O}+\mathrm{K}_{2} \mathrm{O}\right)$ plot of investigated tuff as well as previous published data $[4,5,8,14,41-43]$.

\section{3. ${ }^{40}$ Ar $/{ }^{39}$ Ar Dating}

Regionally after the Mid Badenian climatic optimum, evaporitic formation and lithological changes occur related to restricted circulation for which both cooling and associated drop of sea-level were responsible in the Alpine-Carpathian realm [11,44,45].

${ }^{40} \mathrm{Ar} /{ }^{39} \mathrm{Ar}$ dating of biotite concentrate from the white tuff gives an age of $13.7 \pm 0.2 \mathrm{Ma}$ (Table 2), the dated tuff being situated above the FO of G. druryi and G. transsilvanica [27,28] (Figure 2), which marked the base of Wielician substage. Hohenegger et al. (2014) positioned the base of this substage at 13.82 Ma corresponding to the Langhian/Serravallian boundary [30]. From this level upward discrete gypsum layers occurs within the green tuffs, thus the age may be considered indicating for this sector the onset of the restrictive circulation. The regional distribution of Badenian evaporites in the Carpathian realm is shown in Figure 5. For the northern Carpathian sector, the beginning of the restricted circulation in Paratethys area occurred about $14 \mathrm{Ma}$ ago, with asynchronous evaporites formation, gypsum occurrence being older toward the Carpathian chain and younger toward the platform [44].

In Figure 6, the biostratigraphical markers-the position of dated tuffs from the extra and inter-Carpathian realm - are shown along with the new determined age of $13.7 \pm 0.2 \mathrm{Ma}$ on a biotite concentrate from the white tuff level occurring at Slănic. As in the present case, at the Green Stone Hill, salt breccia and massive gypsum occurs above the dated tuff level indicating $13.7 \pm 0.2 \mathrm{Ma}$ (Figure 2), the main evaporitic episode is younger than for example the lower tuff level WT-1 dated for Wieliczka [46] with $13.8 \pm 0.06 \mathrm{Ma}$. Also, salt accumulation started in the Carpathians with about $0.4 \mathrm{Ma}$ latter than the main Badenian cooling event for which, in the Parathetys, an age of 14.2 Ma was estimated [11]. 


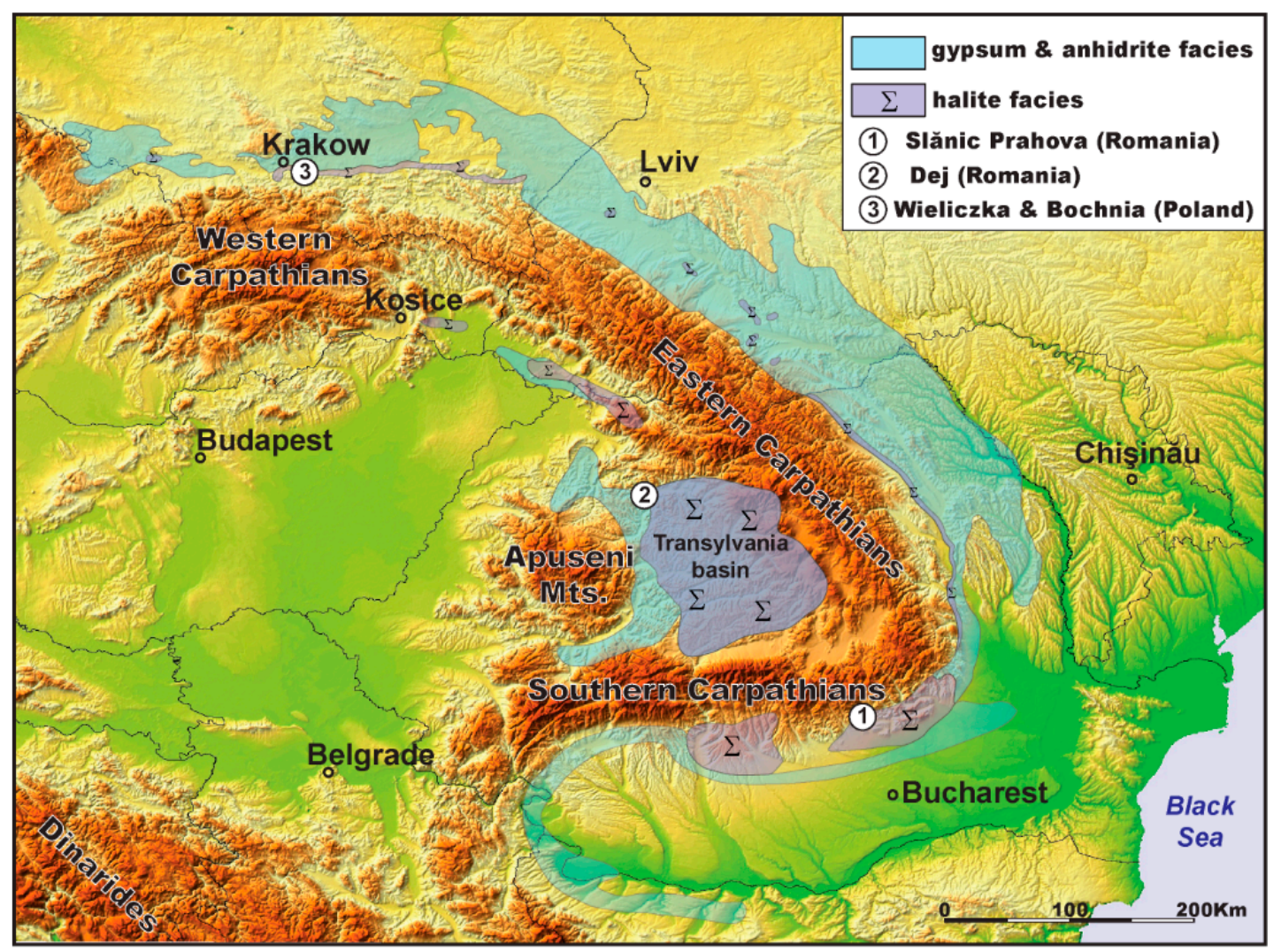

Figure 5. Areal distribution of Late Badenian evaporitic deposits in the Carpathian area. 


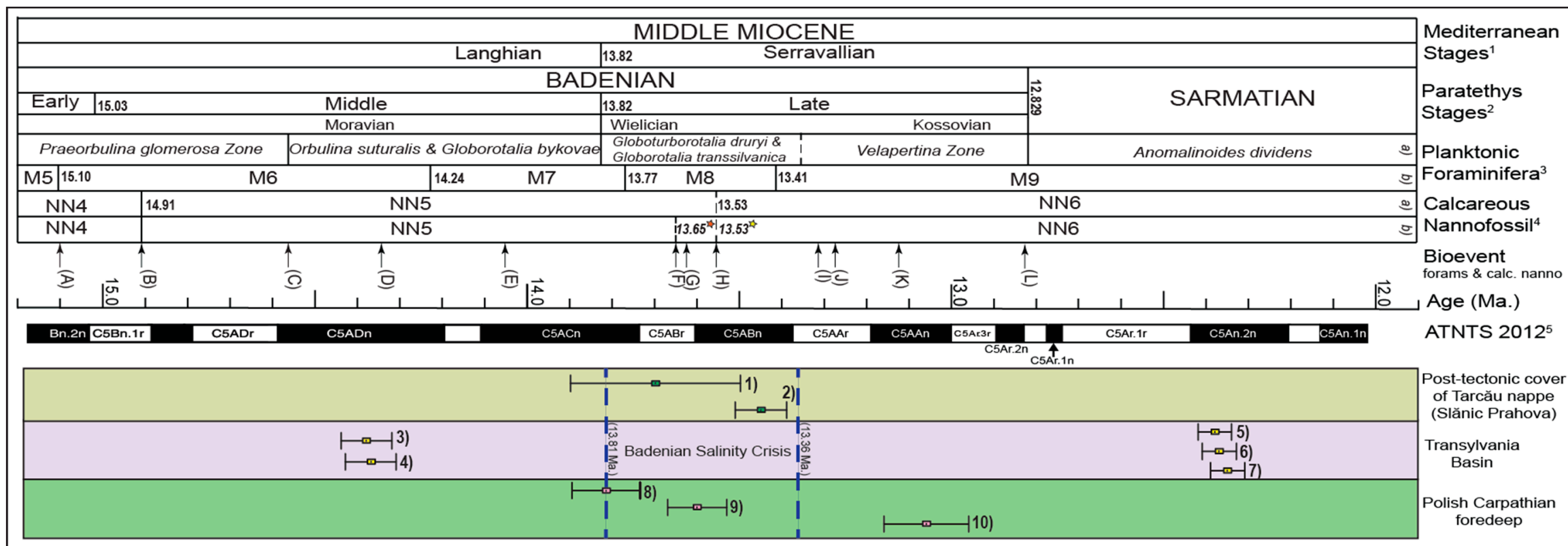

4) Dej tuff ( $14.37 \pm 0.06 \mathrm{Ma})$, Leeuw et al., 2013

3) Ciceu Giurgești tuff ( $14.38 \pm 0.06 \mathrm{Ma}$ ), Leeuw et al., 2013

(pyroclastic deposits underlying the Badenian salt deposits)

2) tuff level (13.45 $\pm 0.06 \mathrm{Ma}$ ) inside the Radiolarian Shale Fm, Leeuw et al., 2012

(pyroclastic deposits from the Radiolarian Shale Fm that overlie the Badenian evaporites)

1) tuff level $(13.70 \pm 0.2 \mathrm{Ma})$ inside the Slănic Tuff $F \mathrm{~m}$., Bojar et al., in this study

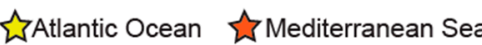

10) tuff level (13.06 $\pm 0.1 \mathrm{Ma}$ ) inside the Pecten beds Fm. (Sliwinski et al., 2012) 9) tuff level (13.60 $\pm 0.07 \mathrm{Ma}$ ) inside the salt (Leeuw et al., 2010)

8) tuff level (13.81 $\pm 0.08 \mathrm{Ma}$ ) bellow the salt (Leeuw et al., 2010)

7) Campia Turzi tuff ( $12.35 \pm 0.04 \mathrm{Ma})$, Leeuw et al., 2013

6) Turda tuff $(12.37 \pm 0.04 \mathrm{Ma})$ \& Hadareni tuff $(12.37 \pm 0.04 \mathrm{Ma})$, Leeuw et al., 2013 5) Ghiriş tuff (12.38 $\pm 0.04 \mathrm{Ma})$, Leeuw et al., 2013

Figure 6. Geochronological and lithostratigraphical position of the investigated tuff level and regional correlations. (1) and (5) after [30]; (2) after [31]; (3a) after [28] and (3b) after [47]; (4a) [34] vide [31]; (4b) after [48]; (5-9) after [46] and (10) after [49]. General bioevents: (A) FO Praeorbulina glomerosa, 15.01 Ma, Western Mediteraneean, [50]; (B) HO Helicosphaera ampliaperta, $14.91 \mathrm{Ma}$ [51]; (C) FO Orbulina suturalis, $14.56 \mathrm{Ma}$, Western Mediterranean [50]; (D) LOC Helicosphaera waltrans, 14.35 Ma, Western Mediterranean [50]; (E) FCO Helicosphaera walbersdorfensis, 14.053 Ma, Western Mediterranean [50]; (F) HO Sphenolithus heteromorphus, 13.65 Ma, Eastern Mediterranean [51]; (G) LCO Sphenolithus heteromorphus, 13.63 Ma, Western Mediterranean [50]; (H) HO Sphenolithus heteromorphus, 13.532 Ma, Atlantic [51]; (I) LCO Cyclicargolithus floridanus, $13.30 \mathrm{Ma}$, Western Mediterranean [50]; (J) HCO Cyclicargolithus floridanus, 13.28 Ma, Eastern Mediterranean [51]; (K) FCO Reticulofenestra pseudoumbilicus, 13.13 Ma [50]; (L) base Reticulofenestra pseudoumbilicus, 12.83 Ma [52]. Absolute age data: Polish Carpathian foredeep [46,51]; Transylvania basin [3]; Slănic Prahova [33]. 
Acknowledgments: Regretfully, Stanisław Hałas, co-author of this study, passed away in May 2017. During these difficult times, all our sympathies are with his family. OEAD is acknowledged for supporting cooperation. We thank to the editor and two anonymous reviewers, which improved our manuscript with their comments and suggestions. Special issue editor, Christophe Lécuyer is thanked for professional assistance.

Author Contributions: Ana-Voica Bojar: concept, field work, text writing, sample preparation, figures; Barbu Victor: text writing, figures; Hans-Peter Bojar: field work, mineralogy, text writing; Stanislaw Halas and Artur Wojtowic: sample preparation, Ar-Ar dating, text writing; Octavian Duliu: text writing, statistics.

Conflicts of Interest: The authors declare no conflict of interest.

\section{References}

1. Ciupagea, D.; Păucă, M.; Ichim, T. Geology of the Transylvanian Depression; Editura Academiei R.S.R.: Bucharest, Romania, 1970; 256p. (In Romanian)

2. Seghedi, I.; Szakács, A.; Vanghelie, I.; Costea, C. Zeolite formation in the lower Miocene tuffs, North Western Transylvania, Romania. Romanian J. Miner. 2000, 80, 11-20.

3. De Leeuw, A.; Filipescu, S.; Maţenco, L.; Krijgsman, W.; Kuiper, K.F.; Stoica, M. Paleomagnetic and chronostratigraphic constraints on the Middle to Late Miocene evolution of the Transylvanian Basin (Romania): Implications for Central Paratethys stratigraphy and emplacement of the Tisza-Dacia plate. Glob. Planet. Chang. 2013, 103, 82-98. [CrossRef]

4. Balint, R.; Calotescu, L.G.; Boero, V.; Ajmone-Marsan, F. Clay minerals clinoptilolite assemblages in two Romanian tuffs. Carpathian J. Earth Environ. Sci. 2015, 10, 27-39.

5. Cochemé, J.J.; Leggo, P.J.; Damian, G.; Fülop, A.; Ledesert, B.; Grauby, O. The mineralogy and distribution of zeolitic tuffs in the Maramures Basin, Romania. Clays Clay Miner. 2003, 51, 599-608. [CrossRef]

6. Damian, G.; Damian, F.; Macovei, G.; Constantina, C.; Iepure, G. Zeolitic Tuffs from Coştiui zone-Maramureş Basin. Carpathian J. Earth Environ. Sci. 2007, 2, 59-74.

7. Kovács, M.; Fülop, A. Neogene volcanism in Gutâi Mts. (Eastern Carpathians): A review. Stud. UBB Geol. 2003, 48, 3-16. [CrossRef]

8. Seghedi, I.; Downes, H.; Szakács, A.; Mason, P.R.D.; Thirlwall, M.F.; Roşu, E.; Pécskay, Z.; Marton, E.; Panaiotu, C. Neogene-Quaternary magmatism and geodynamics in the Carpathian-Pannonian region: A synthesis. Lithos 2004, 72, 117-146. [CrossRef]

9. Bojar, A.-V.; Barbu, V.; Bojar, H.-P. Middle Miocene zeolite-bearing turbidites, Abrămuţ Basin (Pannonian Basin), NW Romania. Geol. Q. 2012, 56, 261-268. [CrossRef]

10. Pécskay, Z.; Lexa, J.; Szakács, A.; Seghedi, I.; Balogh, K.; Koneèny, V.; Zelenka, T.; Kovács, M.; Póks, T.; Fülöp, A.; et al. Geochronology of Neogene magmatism in the Carpathian arc and intra-Carpathian area. Geol. Carpathian 2006, 57, 511-530.

11. Bojar, A.-V.; Hiden, H.; Fenninger, A.; Neubauer, F. Middle Miocene seasonal temperature changes in the Styrian Basin, Austria, as recorded by the isotopic composition of Pectinid and Brachiopod shells. Palaeogeogr Palaeoclimatol. Palaeoecol. 2004, 203, 95-105. [CrossRef]

12. Handler, R.; Ebner, F.; Neubauer, F.; Bojar, A.-V.; Hermann, S. ${ }^{4}{ }_{\mathrm{a}}{ }^{/ 39}$ Ar dating of Miocene tuffs from the Styrian part of the Pannonian basin: An attempt to refine basin stratigraphy. Geol. Carpathian 2006, 57, 483-494.

13. Mărunţeanu, M. Litho- and biostratigraphy (calcareous nannoplankton) of the Miocene deposits from the Outer Moldavides. Geol. Carpathian 1999, 50, 313-324.

14. Calotescu, L.G.; Boero, V.; Franchini, M.A. Zeolites occurrence in Miocene pyroclastites of Slănic-Prahova (Romania). Stud. Surf. Sci. Catal. 2005, 155, 117-128. [CrossRef]

15. Săndulescu, M. Geotectonica României; Editura Tehnică: Bucharest, Romania, 1984; 450p. (In Romanian)

16. Ştefănescu, M.; Mărunţeanu, M. Age of the Doftana Molasse. Dări de Seamă ale Sedinţelor Institutului de Geologie şi Geofizică 1980, 65, 169-182.

17. Popescu, G. Marine Middle Miocene microbiostratigraphical correlation in Central Paratethys. Dări de Seamă ale Sedinţelor Institutului de Geologie şi Geofizică 1987, 72-73, 149-168.

18. Papaianopol, I.; Mărunţeanu, M. Biostratigraphie (Mollusques, Nannoplancton) du Sarmatien et du Meotien de l'est de Muntenia (Bassin Dacique, Roumanie). Analele Universităţii Al. I. Cuza 1992, 28-29, 291-300.

19. Marinescu, F.; Mărunţeanu, M.; Papaianopol, I.; Popescu, G. Tables with the correlation of the Neogene deposits in Romania. Romanian J. Stratigr. 1998, 78, 181-186. 
20. Visarion, M.; Săndulescu, M.; Stănică, D.; Atanasiu, L. An improved geotectonic model of the East Carpathians. Rev. Roum. Géol. Géophys. Géogr. Serie Geophys. 1988, 32, 43-52.

21. Maţenco, L.; Bertotti, G.; Cloetingh, S.; Dinu, C. Subsidence analysis and tectonic evolution of the external Carpathian-Moesian Platform region during Neogene times. Sediment. Geol. 2003, 156, 71-94. [CrossRef]

22. Ş̦tefănescu, M.; Rădan, S.; Micu, M.; Mărunţeanu, M.; Ştefănescu, M. Geological Map of Romania, Scale 1:50.000, Sheet 129b Slănic (Prahova); Geological Institute of Romania: Bucharest, Romania, 1978.

23. Popescu, G. Observaţii asupra breciei sării şi a unor masive de sare din regiunea paleogen-miocenă a judeţului Prahova. Dări de Seamă ale Institutului Geologic 1951, 32, 3-13.

24. Georgescu, O.; Frunzescu, D.; Drăgănescu, L.; Stamate, I. Considérations génétiques concernant les séquences évaporitiques de Slănic Prahova. In The Miocene from the Transylvanian Basin-Romania; Bedelean, I., Ed.; Editura Carpatica: Cluj-Napoca, Romania, 1994; pp. 217-224.

25. Melinte-Dobrinescu, M.C.; Stoica, M. Badenian calcareous nannofossil fluctuation in the Eastern Carpathians: Palaeoenvironmental significance. Acta Palaeontol. Romaniae 2014, 9, 47-57.

26. Dumitrică, P.; Gheta, N.; Popescu, G. Date noi cu privire la biostratigrafia si corelarea Miocenului mediu din aria carpatica. Dări de Seamă ale Sedinţelor Institutului de Geologie şi Geofizică 1975, 61, 65-81.

27. Crihan, I.M. Middle Miocene Litho- and Biostratigraphical Study between Prahova Valley and Teleajen Valley, at Southern Part of the Slănic Syncline. Ph.D. Thesis, Babeş-Bolyai University, Cluj-Napoca, Romania, 1999.

28. Popescu, G. Lower and Middle Miocene Agglutinated Foraminifera from the Carpathian Area. Acta Palaeontol. Romaniae 1999, 2, 407-425.

29. Frunzescu, D. Miocene evaporites from the southern part of Eastern Carpathians-Sedimentological approach. Romanian J. Miner. Depos. 2010, 85, 23-30.

30. Hilgen, F.; Lourens, L.J.; van Dam, J.A. The Neogene period. In The Time Geologic Scale 2012; Gradstein, F.M., Ogg, J.G., Schmitz, M.A., Ogg, G.M., Eds.; Elsevier: Amsterdam, The Netherlands, 2012; pp. 1083-1127. ISBN 978-0-444-59425-9.

31. Hohenegger, J.; Ćorić, S.; Wagreichv, M. Timing of the Middle Miocene Badenian Stage of the Central Paratethys. Geol. Carpathian 2014, 65, 55-66. [CrossRef]

32. Popescu, G.; Crihan, I.M. Middle Miocene Globigerinas of Romania. Acta Palaeontol. Romaniae 2011, 7, $291-314$.

33. De Leeuw, A.; Bukowski, K.; Krijgsman, W.; Kuiper, K.F.; Stoica, M.; Tulbure, M. Chronology of the Badenian Salinity Crisis of the Central Paratethys. In Proceedings of the Paratethys-Mediterranean Interactions: Environmental Crises during the Neogene, Abstract volume RCMNS Colloqium, Bucharest, Romania, 27-28 September 2012.

34. Martini, E. Standard Tertiary and Quaternary calcareous nannoplankton zonation. In Proceedings of $2 n d$ Planktonic Conference 1970; Tecnoscienza: Roma, Italy, 1971; pp. 739-785.

35. Pouchou, J.L.; Pichoir, F. Quantitative analysis of homogeneous or stratified microvolumes applying the model 'PAP'. In Electron Probe Quantitation; Heinrich, K.F.J., Newbury, D.E., Eds.; Plenum Press: New York, NY, USA, 2012; pp. 31-75.

36. Samson, S.D.; Alexander, E.C., Jr. Calibration of the interlaboratory ${ }^{4}$ iãAr- ${ }^{39}$ Ar dating standard, MMhb-1. Chem. Geol. Isotope Geosci. Sect. 1987, 66, 27-34. [CrossRef]

37. Coombs, D.S.; Alberti, A.; Armbruster, T.; Artioli, G.; Colella, C.; Galli, E.; Grice, J.D.; Liebau, F.; Mandarino, J.A.; Minato, H.; et al. Recommended nomenclature for zeolite minerals: Report of the Subcommittee on Zeolites of the International Mineralogical Association, Commission on New Minerals and Mineral Names. Can. Mineral. 1997, 35, 1571-1606. [CrossRef]

38. Ijima, A.; Ogihara, S. Zeolites in Petroleum and Natural Gas Reservoirs in Japan: A Review. In Natural Zeolites '93; Occurrence, Properties, Use; Ming, D.W., Mumpton, F.A., Eds.; International Committee on Natural Zeolites: Brockport, NY, USA, 1995; pp. 99-114.

39. Sanders, C. Tectonics and Erosion, Competitive Forces in a Compressive Orogen. A Fission Track Study of the Romanian Carpathians. Ph.D. Thesis, Vrije Universiteit, Amsterdam, The Netherlands, 1998.

40. Ijima, A. Zeolites in petroleum and natural gas reservoires. Rev. Miner. Geochem. 2001, 45, 347-402. [CrossRef]

41. Bedelean, H.; Codrea, V.; Barbu, O. Geological and mineralogical characterization of some zeolitized tuffs from NW Transylvania, Romania. Bull. Geol. Soc. Greece 2007, 40, 666-675.

42. Bedelean, H.; Măicănean, A.; Burcă, S.; Stanca, M. Investigations on some zeolitic volcanic tuffs from Cluj County (Romania), used for zinc ions removal from aqueous solution. Stud. UBB Geol. 2010, 55, 9-15. [CrossRef] 
43. Damian, G.; Pop, N.; Kovacs, P.P. La pétrologie des tufs volcaniques badénienne du Bassin Maramureş. In The Volcanic Tuffs from the Transylvanian Basin; Mârza, I., Ed.; Geological Formations of Transylvania, Romania; University of Cluj-Napoca: Cluj-Napoca, Romania, 1991; Volume 3, pp. 233-243.

44. Peryt, T.M. The beginning, development and termination of the Middle Miocene Badenian salinity crisis in Central Paratethys. Sediment. Geol. 2006, 188-189, 379-396. [CrossRef]

45. Bukowski, K.; de Leeuw, A.; Gonera, M. Isotopic Events Preceding the Badenian Salinity Crisis in the Central Paratethys, Middle Miocene, Poland. In STRATI 2013; Rocha, R., Pais, J., Kullberg, J., Finney, S., Eds.; Springer Geology: Cham, Switzerland, 2014; pp. 837-838. [CrossRef]

46. Leeuw, A.; Bukowski, K.; Krijgsman, W.; Kuiper, K.F. Age of the Badenian Salinity Crisis; impact of Miocene climate variability on the circum-Mediterranean region. Geology 2010, 38, 715-718. [CrossRef]

47. Wade, S.B.; Pearson, N.P.; Berggren, A.W.; Pälike, H. Review and revision of Cenozoic tropical planktonic foraminiferal biostratigraphy and calibration to the geomagnetic polarity and astronomical time scale. Earth Sci. Rev. 2011, 104, 111-142. [CrossRef]

48. Anthonissen, E.; Ogg, J.G. Appendix 3. Cenozoic and Cretaceous biochronology of planktonic foraminifera and calcareous nannofossils. In The Time Geologic Scale 2012; Gradstein, F.M., Ogg, J.G., Schmitz, M.A., Ogg, G.M., Eds.; Elsevier: Amsterdam, The Netherlands, 2012; pp. 1083-1127. ISBN 978-0-444-59425-9.

49. Śliwiński, M.; Bábel, M.; Nejbert, K.; Olszewska-Nejbert, D.; Gásiewicz, A.; Schreiber, B.C.; Benowitz, J.A.; Layer, P. Badenian-Sarmatian chronostratigraphy in the Polish Carpathian foredeep. Palaeogeogr. Palaeoclimatol. Palaeoecol. 2012, 326-328, 12-29. [CrossRef]

50. Abdul Aziz, H.; Di Stefano, A.; Foresi, L.M.; Hilgen, F.J.; Iaccarino, S.M.; Kuiper, K.F.; Lirer, F.; Salvatorini, G.; Turco, E. Integrated stratigraphy and ${ }^{4} ; \mathrm{a} \mathrm{Ar} /{ }^{39} \mathrm{Ar}$ chronology of early Middle Miocene sediments from DSDP Leg 42A, Site 372 (Western Mediterranean). Palaeogeogr. Palaeoclimatol. Palaeoecol. 2008, 257, 123-138. [CrossRef]

51. Raffi, I.; Backman, J.; Fornaciari, E.; Pälike, H.; Rio, D.; Lourens, L.; Hilgen, F. A review of calcareous nannofossil astrobiochronology encompassing the past 25 million years. Quat. Sci. Rev. 2006, 25, 3113-3137. [CrossRef]

52. Wagreich, M.; Hohenegger, J.; Ćorić, S. Base and new definition of the Lower Badenian and the age of the Badenian stratotype (Middle Miocene, Central Paratethys). In STRATI 2013; Rocha, R., Pais, J., Kullberg, J., Finney, S., Eds.; Springer Geology: Cham, Switzerland, 2014; pp. 615-618. [CrossRef] 